\title{
Purification, Properties and Immunological Detection of a Bromoperoxidase-Catalase from Streptomyces venezuelae and from a Chloramphenicol-nonproducing Mutant
}

\author{
By MARTIN KNOCH, KARL-HEINZ VAN PÉE, LEO C. VINING $\dagger$ \\ AND FRANZ LINGENS* \\ Institut für Mikrobiologie der Universität Hohenheim, Garbenstraße 30 , \\ D-7000 Stuttgart 70, FRG
}

(Received 4 January 1989; revised 20 April 1989; accepted 25 May 1989)

\begin{abstract}
A new bromoperoxidase-catalase was purified from the chloramphenicol-producing actinomycete Streptomyces venezuelae ISP 5230. The homogeneous enzyme showed brominating activity, catalase activity and a very low peroxidase activity. The spectral properties and $\mathrm{pH}$ dependence of the catalase activity showed similarities to conventional catalases. In contrast to other haembromoperoxidases, the bromoperoxidase-catalase was stable when treated with an ethanol/ chloroform mixture. Gel filtration gave an estimated $M_{\mathrm{r}}$ of 127000-136000. SDS-PAGE showed a single band corresponding in mobility to a species with an $M_{\mathrm{r}}$ of 61000 . The pI was estimated to be 4.5 . The bromoperoxidase-catalase was not present in active form in a mutant of $S$. venezuelae ISP 5230 , blocked in the chlorination step of chloramphenicol biosynthesis. However, an inactive species of the enzyme was detected in crude extracts of the mutant by using antibodies. From these results it is concluded that this bromoperoxidase participates in the chlorination step during chloramphenicol biosynthesis.
\end{abstract}

\section{INTRODUCTION}

Many fungi, bacteria and other micro-organisms produce a diversity of chlorinated products. However, most of the halogenating enzymes isolated are bromoperoxidases (Neidleman \& Geigert, 1986). These usually resemble the bromoperoxidase from Streptomyces phaeochromogenes (van Pée \& Lingens, 1985) in being haem-containing enzymes, but in the last few years, nonhaem-haloperoxidases have been detected in several organisms, including bacteria (van Pée et al., 1987; Wiesner et al., 1986). Haem-bromoperoxidases catalyse the oxidation of a wide spectrum of organic substrates in the presence of hydrogen peroxide, and also catalyse the oxidation of halide ions. However, only the chloroperoxidase of the mould Caldariomyces fumago (Morris \& Hager, 1966) and the nonhaem-chloroperoxidases of Curvularia inaequalis (Liu et al., 1987) and of Pseudomonas pyrrocinia (Wiesner et al., 1986, 1988) catalyse chlorination. Although haloperoxidases are presumed to function in the biosynthesis of naturally occurring halometabolites, only the chloroperoxidases of $C$. fumago and $P$. pyrrocinia have so far been shown to participate in vivo.

Streptomyces venezuelae produces the chlorinated antibiotic chloramphenicol. Although much is known about chloramphenicol biosynthesis (Vining \& Westlake, 1984), little information about the chlorination step is available. It has been suggested that malonyl-CoA is the substrate that is chlorinated, but the evidence is equivocal and does not exclude the possibility that chlorination follows acylation (Simonsen et al., 1978).

Here we describe the isolation and some properties of a bromoperoxidase-catalase from $S$. venezuelae, and we present evidence that this enzyme exists only as an inactive protein in a mutant blocked in the chlorination step (Doull et al., 1985).

$\dagger$ Present address: Department of Biology, Dalhousie University, Halifax, Nova Scotia B3H 4JI, Canada. 


\section{METHODS}

Chemicals. Monochlorodimedone, o-dianisidine (3,3'-dimethoxybenzidine), nitro blue tetrazolium, phenol red and phosphatase-conjugated anti-rabbit IgG were purchased from Sigma. Hydrogen peroxide $(30 \%$, v/v) was from Merck. L-Isoleucine was a gift from Degussa. 1-Methyl-2-(3,5-dibromo-2-methoxyphenyl)pyrrole was a gift from H. Pudleiner and H. Laatsch, University of Göttingen, FRG.

Bacterial strains. Streptomyces venezuelae ISP 5230 (ATCC 10712) wild-type and its chloramphenicolnonproducing mutant strain $\mathrm{Cml}-2$ were used (Doull et al., 1985).

Growth conditions and preparation of cell extracts. The strains were maintained and propagated routinely on maltmedium. Cells for preparation of extracts were grown in a medium containing glucose, isoleucine and basal salts as described by Doull et al. (1985) for chloramphenicol production. Portions ( $50 \mathrm{ml}$ ) of medium were inoculated with $0.1 \mathrm{ml}$ of a well-grown culture and incubated on a rotary shaker at $30^{\circ} \mathrm{C}$. After $48 \mathrm{~h}$, these cultures were each transferred aseptically into 21 Erlenmeyer flasks containing $500 \mathrm{ml}$ of medium and incubated for a further $96 \mathrm{~h}$. Cultures of the mutant strain were grown for only $72 \mathrm{~h}$ because of their much better growth. Cells were harvested by centrifugation, yielding about $6 \mathrm{~g}$ (wet wt) $1^{-1}$ and frozen at $-18^{\circ} \mathrm{C}$. For disruption, one part of cells (wet wt) was resuspended in two parts (by wt) of $0.1 \mathrm{M}$-ammonium acetate buffer (pH 6.5) and sonicated with a Branson sonifier for fifteen $30 \mathrm{~s}$ periods. After centrifugation at $22100 \mathrm{~g}$ and $4{ }^{\circ} \mathrm{C}$ for $30 \mathrm{~min}$, the supernatant was retained and the cell debris was resuspended in an equal amount of buffer and sonicated as above. The homogenate was centrifuged as above and the supernatants were combined.

Enzyme assays. Brominating activity was measured by the method of Hewson \& Hager (1980) with monochlorodimedone ( $44 \mathrm{mM}$ ) as substrate in the presence of $\mathrm{H}_{2} \mathrm{O}_{2}(1.8 \mathrm{mM})$, bromide $(100 \mathrm{mM})$ and a suitable amount of enzyme in $500 \mathrm{~mm}$-sodium acetate buffer (pH 5.5). The peroxidase assay was done as described by Claiborne \& Fridovich (1979) with $o$-dianisidine hydrochloride $(48 \mu \mathrm{M})$ as substrate in the presence of $\mathrm{H}_{2} \mathrm{O}_{2}$ (7.2 mM) and a suitable amount of enzyme in $100 \mathrm{~mm}$-sodium acetate buffer (pH 5.5). The oxidation of $o$-dianisidine was followed at $460 \mathrm{~nm}$. Catalase activity was assayed spectrophotometrically at $240 \mathrm{~nm}$ (Beers \& Sizer, 1952) with $\mathrm{H}_{2} \mathrm{O}_{2}(6.5 \mathrm{mM})$ as substrate in 100 mM-sodium acetate buffer (pH 5.5). All assays were started by adding the enzyme and absorbance changes were measured against appropriate blanks with a recording spectrophotometer. Specific activities were calculated using the molar extinction coefficient of the substrates or the products, respectively. One unit of activity is defined as the disappearance of $1 \mu \mathrm{mol}$ substrate or the formation of $1 \mu \mathrm{mol}$ of product $\min ^{-1}$ (mg protein) ${ }^{-1}$

Analysis of the bromoperoxidase-catalase by $P A G E$ and analytical isoelectric focusing. For electrophoresis of the native enzyme, $7 \cdot 5 \%(\mathrm{w} / \mathrm{v})$ polyacrylamide gels, $\mathrm{pH} 7 \cdot 5$, according to Maurer (1968) were used. PAGE in the presence of $0.1 \%$ SDS was done according to Laemmli (1970). Proteins in the Pharmacia low molecular mass kit were used as standards. For analytical isoelectric focusing, an LKB thin-layer polyacrylamide gel $(5 \%$, w/v) was used in the $\mathrm{pH}$ range 4.0-6.5. As protein standards, the Pharmacia isoelectric focusing calibration kit (2.5-6.5) was used. The pI was determined by comparison with the migration rates of standard proteins. All electrophoresis was done with an LKB 2117 Multiphore apparatus.

Staining of gels. Gels were stained for protein with Coomassie Blue R250 and for peroxidase activity with $o$-dianisidine to form brown bands (Shannon et al., 1966). To detect brominating activity, phenol red was used as a substrate; this is brominated to bromophenol blue (Loo et al., 1964). The assay mixture contained $0.5 \mathrm{M}$-sodium acetate buffer (pH 5.5), hydrogen peroxide (7.2 mM), 0.1 M-sodium bromide and $0.002 \%$ phenol red. For enzymebound haemferric ions, benzidine dye was used as described by Clarke (1964).

Purification of bromoperoxidase. (1) DEAE-cellulose DE 52. After treatment with $1.5 \%$ (w/v) streptomycin sulphate and centrifugation, the crude extract was applied to a DEAE cellulose DE 52 column $(5 \cdot 5 \times 11 \mathrm{~cm})$ equilibrated with $0.15 \mathrm{M}$-sodium acetate buffer ( $\mathrm{pH} 5.5$ ). The column was washed and then eluted with a gradient $(600 \mathrm{ml})$ of $0.15-0.7 \mathrm{M}$-sodium acetate buffer $\left(\mathrm{pH} \mathrm{5.5)}\right.$. Fractions $(4.2 \mathrm{ml})$ were assayed for protein $\left(A_{280}\right)$, peroxidase and catalase activity. Those with at least $25 \%$ of the activity of the most active fraction were pooled, and the $\mathrm{pH}$ was adjusted to $6 \cdot 5$.

(2) Phenyl-Sepharose $C L-4 B$. Ammonium sulphate was added to the enzyme solution to $1.0 \mathrm{M}$. The solution was then applied to a phenyl-Sepharose CL-4B column $(14 \times 2.5 \mathrm{~cm})$ equilibrated with $0.5 \mathrm{M}$-ammonium sulphate in $10 \mathrm{~mm}$-ammonium acetate buffer, $\mathrm{pH} \mathrm{6.5}$. Protein was eluted with a descending gradient of $0.5-0 \mathrm{M}$-ammonium sulphate $(600 \mathrm{ml}, \mathrm{pH} 6 \cdot 5)$. Fractions were assayed for protein $\left(A_{230}\right)$ and catalase activity, and the active fractions were pooled.

(3) Hydroxyapatite. Without dialysis, the pooled enzyme solution was applied to a hydroxyapatite column $(14 \times 2.5 \mathrm{~cm})$ equilibrated with $10 \mathrm{mM}$-potassium phosphate buffer $(\mathrm{pH} 6.8)$, and eluted with a gradient $(400 \mathrm{ml}$; $10-100 \mathrm{mM})$ of the same buffer. Fractions $(2.8 \mathrm{ml})$ were screened for bromoperoxidase activity as well as for protein $\left(A_{215}\right)$. The active fractions were pooled.

(4) Sepharose $Q$ Fast Flow. The enzyme was applied to a Sepharose Q column $(1 \times 13 \mathrm{~cm})$, equilibrated with $50 \mathrm{~mm}$-ammonium acetate buffer ( $\mathrm{pH} 5 \cdot 6)$. The column was eluted with a gradient $(400 \mathrm{ml})$ of $0-400 \mathrm{mM}-\mathrm{KCl}$ in the same buffer. Fractions were assayed and pooled as in step (3). The solution was dialysed against $10 \mathrm{~mm}-$ 
ammonium acetate buffer (pH 6.5) and concentrated using an Amicon concentrator with a PM-30 membrane.

(5) Phenyl-Sepharose $C L-4 B$. To remove the last impurities, hydrophobic chromatography with phenylSepharose was repeated with a small column $(0.8 \times 4.5 \mathrm{~cm})$.

Preparative PAGE. For production of antisera, the nearly homogeneous enzyme solution from different preparations after four steps of purification was subjected to preparative PAGE. The protein solution was concentrated to a volume of approximately $200 \mu \mathrm{l}$ before being applied to a $4 \mathrm{~mm}$ polyacrylamide gel and electrophoresed as described by Maurer (1968). The brownish band was cut out and stored at $-18^{\circ} \mathrm{C}$.

Immunological procedure. (a) Production of antisera. The frozen gel pieces from the preparative PAGE were cut into four parts containing approximately $0.25 \mathrm{mg}$ bromoperoxidase each, pulverized and suspended in a total volume of $1 \mathrm{ml}$ of phosphate-buffered saline (PBS; $0.13 \mathrm{M}-\mathrm{NaCl}, 0.007 \mathrm{M}-\mathrm{Na}_{2} \mathrm{HPO}_{4}, 0.003 \mathrm{M}-\mathrm{NaH}_{2} \mathrm{PO}_{4}$ ). The probe was given to a rabbit as described by Spielman et al. (1974). After the third booster injection, the rabbit had to be bled, because it had developed abscesses at the injection sites. The serum was checked for precipitating antibodies using the agar double-diffusion test (Ouchterlony, 1949).

(b) Electroblotting of proteins. Proteins were separated by native or SDS-polyacrylamide gel electrophoresis. The proteins were transferred to a nitrocellulose filter $(0.45 \mu \mathrm{m}$ pore size; Schleicher and Schuell) with an LKB Multiphor II NovaBlot. The blotting was done as described in the LKB instruction manual. The discontinuous electrode-solution system for isoelectric focusing gels was used for native gels; a continuous buffer system was used for SDS-PAGE.

(c) Immunological detection of blotted proteins. After transfer of the proteins, the nitrocellulose sheet was submerged in a solution of skimmed milk $(5 \%, \mathrm{v} / \mathrm{v})$ in PBS for $2 \mathrm{~h}$ to block the remaining binding sites. The bromoperoxidase-catalase antiserum was diluted $1: 100$ in blocking solution and the blot was incubated overnight at room-temperature on a rocking platform. The sheet was washed with five aliquots of PBS within $30 \mathrm{~min}$. Alkaline-phosphatase-conjugated anti-antibodies (Sigma) were diluted 1:2000 in blocking solution, added to the nitrocellulose blot and incubated for another $2 \mathrm{~h}$. Further washing and developing of the nitrocellulose blot was done as described by Blake et al. (1984) with 5-bromo-4-chloroindolyl phosphate as a substrate for the alkaline phosphatase reaction. The reaction was stopped after $10 \mathrm{~min}$.

$M_{r}$ determination. The $M_{\mathrm{r}}$ of purified bromoperoxidase-catalase was estimated by molecular-sieve chromatography with a $95 \times 2.5 \mathrm{~cm}$ column of Sephadex G-200. The column was standardized with ferritin $\left(M_{\mathrm{r}}\right.$ 440000), gamma globulin (150000), bovine serum albumin (68000) and ovalbumin (44000). The column was equilibrated with $50 \mathrm{mM}$-ammonium acetate buffer (pH 6.8).

Protein determination. Protein was determined by the Lowry method using bovine serum albumin as a standard.

Spectroscopy. Absorption spectra were recorded on a Uvicon 810 spectrophotometer (Kontron Analytik). For GC-MS, a Varian 3700 mass spectrometer was used. For X-ray fluorescence spectra, a Perkin Elmer model 400 atomic absorption spectrometer was used.

Treatment with chloroform/ethanol. This was done by the method described by Nadler et al. (1986). A solution of purified bromoperoxidase-catalase was mixed with the solvents in the proportions enzyme solution/chloroform/ ethanol (10:5:3, by vol.) and vortexed for $10 \mathrm{~min}$ at room-temperature. After centrifugation for $5 \mathrm{~min}$ to separate the two phases, the upper phase, which contained the enzyme, was assayed for activity.

Bromination of 1-methyl-2-(3,5-dibromo-2-methoxyphenyl)pyrrole by the bromoperoxidase-catalase. To demonstrate the brominating ability of the bromoperoxidase-catalase, we used 1-methyl-2-(3,5-dibromo-2-methoxyphenyl)pyrrole as a substrate. This particular phenylpyrrole derivative was used because it is very sensitive to bromination, but gives no brominated product in the absence of bromoperoxidase. The assay mixture contained 1-methyl-2-(3,5-dibromo-2-methoxyphenyl)pyrrole ( $0.02 \mathrm{mM})$, hydrogen peroxide $(7.2 \mathrm{~mm})$, potassium bromide $(0.5 \mathrm{M})$ and $100 \mathrm{mU}$ of purified bromoperoxidase in sodium acetate buffer $(0.5 \mathrm{M}, \mathrm{pH} 4.75)$. After $16 \mathrm{~h}$ at roomtemperature, the reaction mixture was extracted twice with ethyl acetate. A blank without enzyme was treated in the same way. Reaction products were characterized by GC-MS, with a Varian 3700 mass spectrometer ( $80 \mathrm{eV})$. A $25 \mathrm{~m}$ glass capillary column SE-30 was used. The temperature of the oven was run from $120-240^{\circ} \mathrm{C}$ $\left(10^{\circ} \mathrm{C} \mathrm{min}^{-1}\right)$; the temperatures of the injector and the detector were 250 and $300^{\circ} \mathrm{C}$, respectively.

\section{RESULTS}

\section{Enzyme purification}

No brominating activity could be detected in the crude extract. In the first purification step fractions assayed for catalase activity exhibited two peaks (Fig. 1). Only one of these was associated with peroxidase activity. After further purification of the material in the other peak region, brominating activity (monochlorodimedone assay) was found to accompany the catalase activity. Even in purified material from this peak region no peroxidase activity with $o$-dianisidine was ever detected in the absence of bromide by the spectrophotometric assay. The results of the purification of this component are summarized in Table 1. 

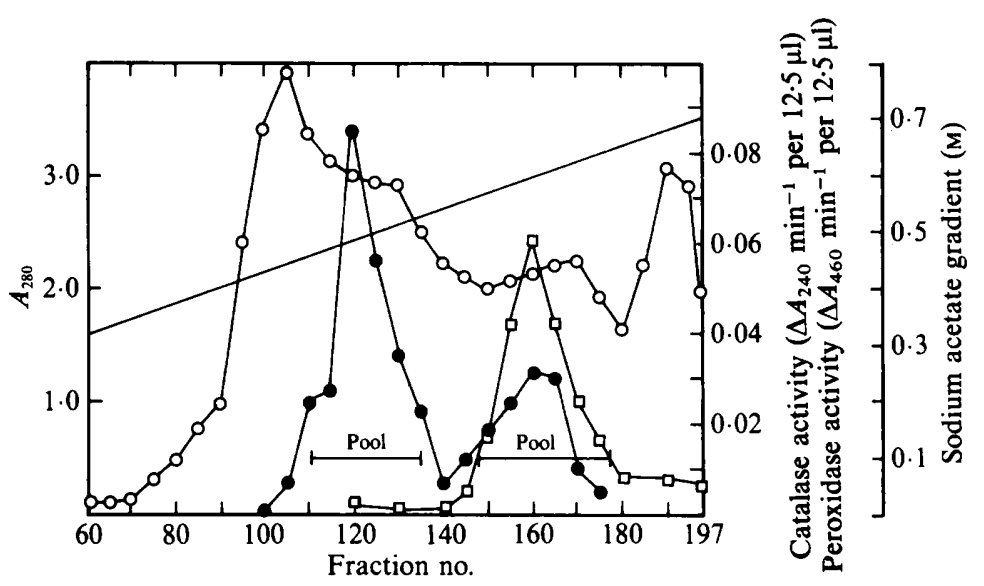

Fig. 1. First ion-exchange chromatography on DEAE-cellulose DE 52 showing the separation of the two catalase activities present in crude extracts of $S$. venezuelae. Fractions of $4.2 \mathrm{ml}$ were collected. $O$, Absorbance at $280 \mathrm{~nm}$; $\bullet$, catalase activity; $\square$, peroxidase activity; - , sodium acetate buffer (pH 5.5) concn.

Table 1. Summary of the purification of bromoperoxidase-catalase from $S$. venezuelae The enzyme was purified from $142 \mathrm{~g}$ bacteria (wet wt). -, Could not be determined; BPO, bromoperoxidase.

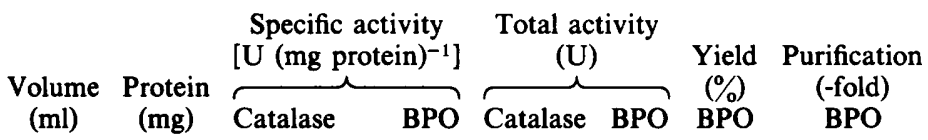

Crude extract $+1 \cdot 5 \%(\mathrm{w} / \mathrm{v})$

streptomycin sulphate

DEAE-cellulose DE 52 (pH 5.5)

$\begin{array}{rcc}595 & 2703 & - \\ 140 & 213 & 3.32 \\ 107 & 17 \cdot 7 & 20 \cdot 7 \\ 86.0 & 3.1 & 85.4 \\ 34.8 & 0.8 & 279 \\ 0.7 & 0.2 & 963\end{array}$

$\begin{array}{cc}- & - \\ 0.002 & 708 \\ 0.049 & 366 \\ 0.255 & 255 \\ 0.599 & 235 \\ 1.77 & 212\end{array}$

$\begin{array}{cc}- & - \\ 0.48 & 100 \\ 0.87 & 184 \\ 0.78 & 162 \\ 0.50 & 104 \\ 0.39 & 81\end{array}$

-
1
22
113
280
789

\section{Homogeneity and enzymic activities of bromoperoxidase-catalase}

The purified bromoperoxidase-catalase showed a single band on analytical PAGE (Fig. 2, lane A). When stained for brominating activity with phenol red, a blue band developed very quickly (Fig. 2, lane C). Staining for peroxidase activity with o-dianisidine (Fig. 2, lane B) and for enzyme-bound ferric iron with benzidine (Fig. 2, lane D) had to be continued for 30 min before faint brownish and blue-brown bands, respectively, became visible. These coincided with the protein band at $R_{F}=0.25$. In the spectrophotometric assay peroxidase activity [0.05 $\mathrm{U}$ (mg protein $)^{-1}$ ] could be measured only in the presence of bromide ions.

The brominating activity of the new enzyme was confirmed by brominating 1-methyl2-(3,5-dibromo-2-methoxyphenyl)pyrrole. The elemental composition of the compounds obtained was established by GC-MS. The gas chromatogram showed four product peaks, the first of which [retention time $\left(R_{t}\right)=9.0 \mathrm{~min}$ ] was also observed in assays without enzyme; it did not correspond to a brominated product. The next two peaks $\left(R_{t}=10.6 \mathrm{~min}\right.$ and $\left.R_{t}=11.6 \mathrm{~min}\right)$ showed a molecular ion at $m / e 503(35.8 \%)$ and isotope peaks at $m / e 505(26 \%), m / e 501(27 \%)$, $m / e 507(7 \%)$ and $m / e 499(6.5 \%)$ (Fig. 3A). The intensity ratio $(1: 4: 6: 4: 1)$ is characteristic for 


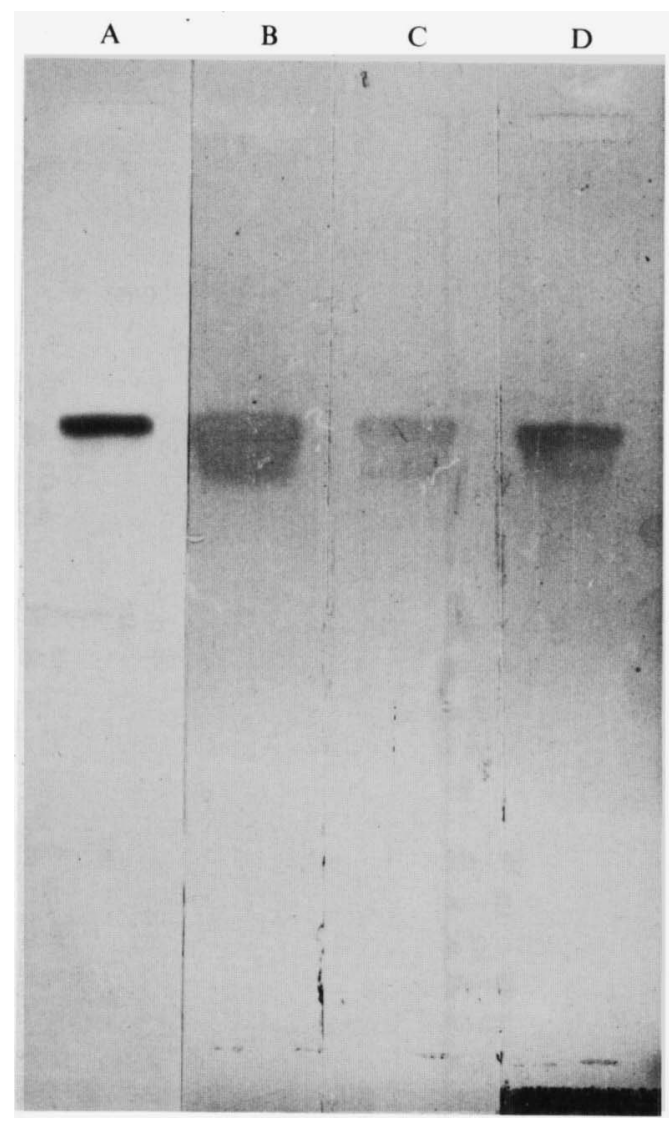

Fig. 2. PAGE of native bromoperoxidase-catalase. Top, cathode; bottom, anode. Lane A, Protein staining with Coomassie Blue; B, staining with $o$-dianisidine for peroxidase activity; $\mathrm{C}$, activity staining with phenol red for brominating activity; D, staining with benzidine for enzyme-bound ferric ions.

a tetrabromo-substituted compound and indicates dibromination of the substrate by the bromoperoxidase-catalase. Peak four $\left(R_{t}=13.3 \mathrm{~min}\right)$ had a molecular ion at $m / e 583$ and isotope peaks with an intensity ratio of $1: 5: 10: 10: 5: 1$ (Fig. 3B), which is characteristic for a pentabromo-substituted molecule and indicates tribromination of the substrate by the bromoperoxidase-catalase.

\section{Spectral properties of the bromoperoxidase-catalase}

The absorption spectrum of the native enzyme is shown in Fig. 4. It had maxima at $403 \mathrm{~nm}$ and $616 \mathrm{~nm}$ with shoulders at $490 \mathrm{~nm}$ and $530 \mathrm{~nm}$. Although addition of $\mathrm{Na}_{2} \mathrm{~S}_{2} \mathrm{O}_{4}$ to the enzyme solution did not shift the Soret peak, it caused loss of the enzyme activity.

\section{Molecular properties}

When the purified enzyme was subjected to SDS-PAGE, only one protein band was detected. The $M_{\mathrm{r}}$ of the subunits of the $S$. venezuelae bromoperoxidase-catalase was 61000 , as determined by SDS-PAGE. The $M_{\mathrm{r}}$ estimated from gel chromatography on Sephadex G-200 and Superose 12 was 127000 and 136000 , respectively. Bromoperoxidase-catalase is thus revealed to be a dimer consisting of two subunits of identical size. 


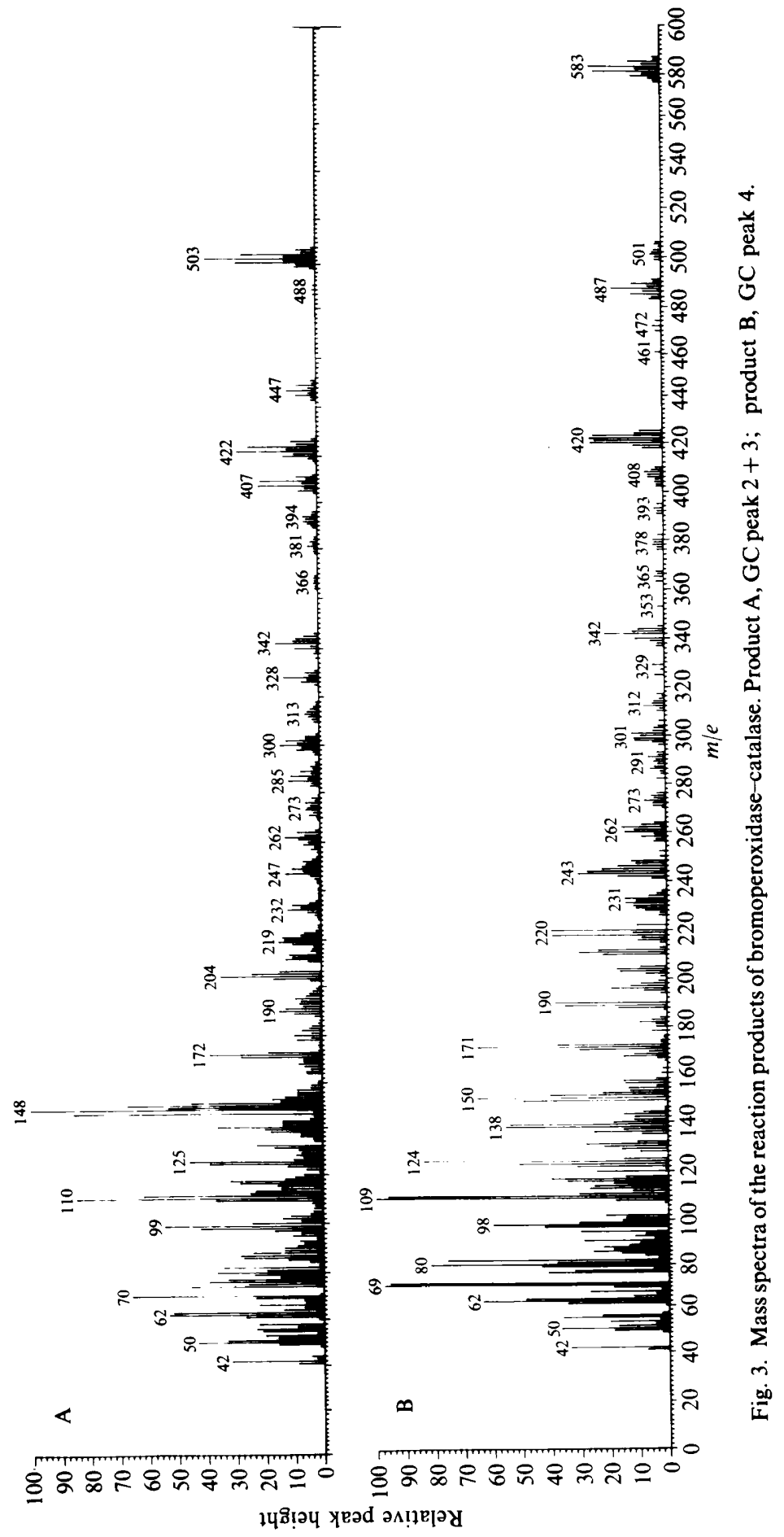




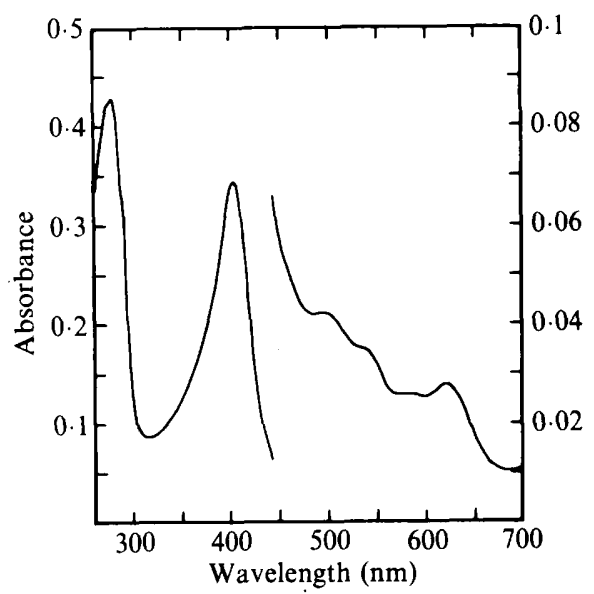

Fig. 4. Absorption spectrum of native bromoperoxidase-catalase. The spectrum was recorded in $10 \mathrm{~mm}$-ammonium acetate buffer ( $\mathrm{pH} \mathrm{6.8)}$.

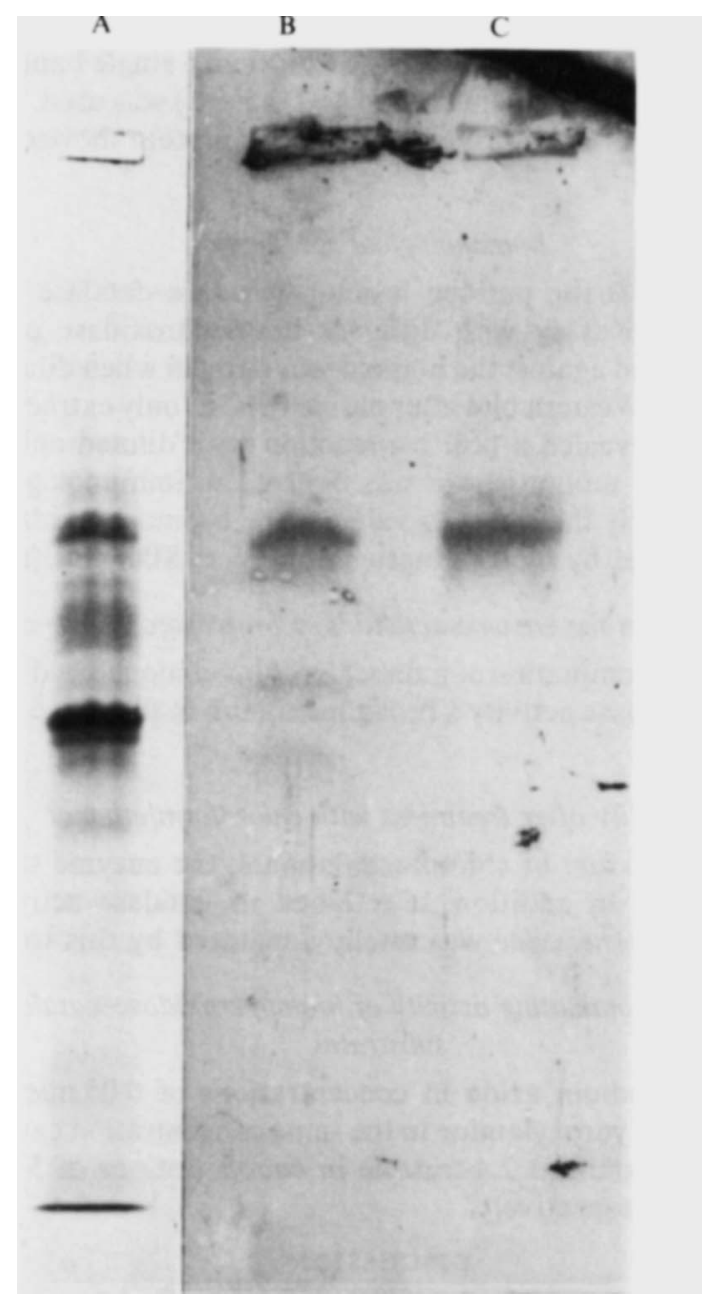

Fig. 5. Native PAGE. Lane A, Crude extract of the non-chlorinating mutant of $S$. venezuelae stained for protein; lane B, Western blot of lane A; lane C, purified bromoperoxidase-catalase. 


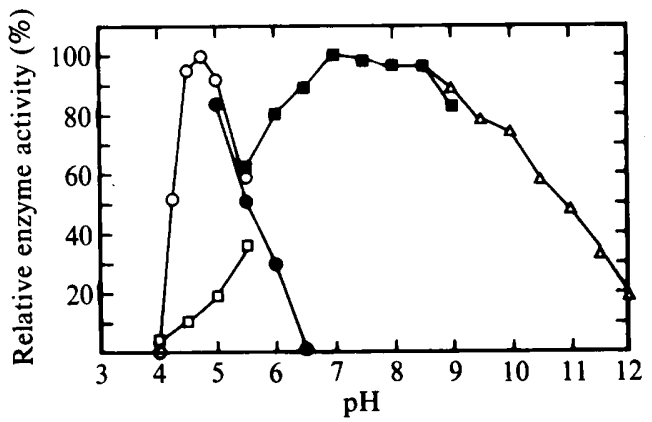

Fig. 6. Brominating and catalase activities of bromoperoxidase-catalase as a function of $\mathrm{pH}$. Brominating activity was measured using the monochlorodimedone assay. The buffers $(0 \cdot 2 \mathrm{M}$ concentration) were sodium acetate $(\mathrm{O}, \mathrm{pH} 4 \cdot 0-5 \cdot 5)$ and ammonium acetate $(0, \mathrm{pH} 5 \cdot 0-6 \cdot 5)$. Catalase activity was measured by following the decomposition of hydrogen peroxide at $240 \mathrm{~nm}$. The buffers (0.2 $\mathrm{M}$ concentration) were sodium acetate $(\square, \mathrm{pH} 4 \cdot 0-5.5)$, potassium phosphate $(\square, \mathrm{pH} 5.5-9.0)$ and glycine/sodium hydroxide $(\triangle, \mathrm{pH} 8 \cdot 5-12)$.

In isoelectric focusing experiments, the enzyme exhibited a single band with an estimated $\mathrm{pI}$ of 4.5 , when a wide-range isoelectric focusing gel ( $\mathrm{pH} \mathrm{3.5-9.5)} \mathrm{was} \mathrm{used.} \mathrm{When} \mathrm{a} \mathrm{narrow-range}$

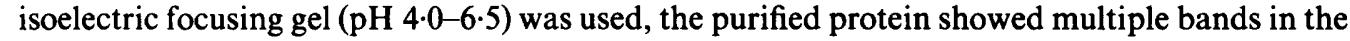
range of $4 \cdot 55-4 \cdot 35$.

\section{Immunological specificity}

Antiserum prepared against the purified bromoperoxidase-catalase was examined by the Ouchterlony double-diffusion assay with different bromoperoxidase preparations. A single precipitation band was formed against the homologous antigen when dilutions up to $1: 32$ of the antiserum were used. On the Western blot after native PAGE, only extracts which contained the bromoperoxidase-catalase revealed a positive reaction with diluted antiserum (Fig. $5 c$ ).

When crude extract of the mutant strain was blotted, an immunological reaction occurred with a protein that had exactly the same $R_{F}$ value as the bromoperoxidase-catalase (Fig. $5 b$ ). The same result was obtained by blotting native as well as SDS gels (result not shown).

\section{Effect of $\mathrm{pH}$ on the enzyme activities of bromoperoxidase-catalase}

The $\mathrm{pH}$ optimum for the bromination of monochlorodimedone showed a distinct maximum at $\mathrm{pH} 4 \cdot 75$, whereas for the catalase activity a broad maximum in the range of $\mathrm{pH}$ 6-9 (Fig. 6) was obtained.

\section{Stability after treatment with chloroform/ethanol}

After treatment with a mixture of chloroform/ethanol, the enzyme still showed $65 \%$ of its initial brominating activity. In addition, it retained its catalase activity. Another bromoperoxidase isolated from $S$. venezuelae was totally denatured by this treatment.

\section{Compounds inhibiting the brominating activity of bromoperoxidase-catalase in the presence of substrates}

Potassium cyanide and sodium azide in concentrations of $0.05 \mathrm{~mm}$ completely inhibited bromoperoxidase-catalase. Hydroxylamine in the same concentration caused $50 \%$ inhibition of the brominating activity; 3-amino-1,2,4-triazole in concentrations of 5 and $40 \mathrm{~mm}$ produced inhibitions of 45 and $90 \%$, respectively.

\section{DISCUSSION}

From soluble extracts of Streptomyces venezuelae a bromoperoxidase-catalase was purified to homogeneity. The enzyme has brominating activity $\left(1.8 \mathrm{U} \mathrm{mg}^{-1}\right)$, catalase activity $\left(963 \mathrm{U} \mathrm{mg}^{-1}\right)$ and insignificant peroxidase activity that is observed-only in the presence of 
bromide ions $\left(0.05 \mathrm{U} \mathrm{mg}^{-1}\right)$. We termed it a bromoperoxidase-catalase to distinguish it from other bacterial haloperoxidases, such as that isolated from $P$. pyrrocinia (Wiesner et al., 1985) and also present in extracts of $S$. venezuelae, which have high peroxidase activity. Brominating activity could be detected only after the first purification steps, as already observed with other bacterial bromoperoxidases (van Pée \& Lingens, 1985). Obviously, there are unknown inhibitory substances present in the crude extract. Previously, catalase was thought to be interfering with the monochlorodimedone assay (van Pée \& Lingens, 1985); however, even when catalase is inhibited or removed by heat treatment, inhibition of brominating activity can be observed in cell-free extracts of bacteria (van Pée et al., 1987). The differences in yield for brominating and catalase activity are due to the fact that the pooled fractions after ion exchange chromatography contain an additional catalase, which is removed in later steps.

To be absolutely sure that the isolated enzyme catalysed bromination of organic compounds, brominating activity of the new enzyme was demonstrated by enzymic bromination of 1-methyl2-(3,5-dibromo-2-methoxyphenyl)pyrrole. This result is important because oxidation of monochlorodimedone by horseradish peroxidase was reported by Griffin \& Ashley (1984). It is also known that haloperoxidases can use hydrogen peroxide to oxidize organic substrates, demonstrated with phenol red, which upon oxidation showed a change of absorbance at $610 \mathrm{~nm}$ (Glenn \& Gold, 1985). Since bromination of phenol red results in a change of absorbance at $592 \mathrm{~nm}$ (de Boer et al., 1987), it is difficult to differentiate between the two reactions, and the assay using phenol red is not very reliable for activity staining.

The enzyme described here is proposed to be a haem-protein since its optical spectrum shows a Soret band. The $405 / 280 \mathrm{~nm}$ ratio of $0 \cdot 6$, the faint staining with benzidine and low content of ferric iron [ 1.55 atoms of iron per molecule of (dimeric) enzyme] is consistent with a low haem content, also shown for other bacterial bromoperoxidases (van Pée \& Lingens, 1985). As with other haem-enzymes, the bromoperoxidase-catalase was inhibited by sodium azide and potassium cyanide. The low specific activity for bromination and the broad $\mathrm{pH}$ optimum (7-8.5) for bromination of monochlorodimedone were similar to those of other haem-containing bromoperoxidases. The enzyme consists of two subunits of identical size but has a distinctly lower $M_{\mathrm{r}}$ than other bacterial haem-bromoperoxidases. However, the striking difference between this and other comparable enzymes is its very low peroxidase activity, only detectable by activity staining after a long incubation period or in the presence of bromide ions.

Contrary to other bacterial haem-bromoperoxidases, the new bromoperoxidase-catalase resembles in some aspects conventional catalases such as that from Micrococcus luteus and the bacterial catalases described by Nadler et al. (1986). As is typical for these enzymes, catalase activity is not lowered by sodium dithionite and is independent of $\mathrm{pH}$ in the range 5-10. That the enzyme has hydrophobic properties is revealed by its stability in chloroform/ethanol and strong binding to phenyl-Sepharose. Its brominating activity was inhibited by 3-amino-1,2,4-triazole. The (very low) peroxidase activity might be due to the 'bifunctional' peroxidase-catalase nature of catalase described by Schoenbaum \& Chance (1976). According to Sichak \& Dounce (1986), peroxidase activity could be due to the haematin group as was shown for denatured catalase monomers.

Active bromoperoxidase-catalase was absent in extracts from a mutant strain of $S$. venezuelae blocked in the chlorination step. Immunological experiments revealed no cross-reaction with other bacterial haem-bromoperoxidases characterized up to now. However, blotting experiments with extracts of the mutant strain showed the presence of an inactive bromoperoxidase-catalase. Chloroperoxidase from Pseudomonas pyrrocinia catalyses the bromination of monochlorodimedone but not the chlorination of this substrate. However, monodechloroaminopyrrolnitrin [4-(2-amino-3-chlorophenyl)pyrrole], an intermediate of pyrrolnitrin biosynthesis, is chlorinated to aminopyrrolnitrin by this chloroperoxidase (Wiesner et al., 1988). This demonstrates the existence of halogenating enzymes with a high substrate specificity concerning chlorination, but not, however, with respect to bromination. Such enzymes can be shown to have bromoperoxidase activity using the monochlorodimedone assay, whereas their chlorinating activity can only be demonstrated by using a 'natural' substrate. The results described above suggest that the bromoperoxidase-catalase isolated from $S$. venezuelae 
and detected in inactive form in the mutant blocked in the chlorination step of chloramphenicol biosynthesis could actually be the chlorinating enzyme that participates in the chlorination step of chloramphenicol biosynthesis. To prove this, however, more information about the nature of the substrate for the chlorination step in chloramphenicol biosynthesis is necessary.

We thank the Fonds der Chemischen Industrie and the Bundesministerium für Forschung und Technologie for financial support.

\section{REFERENCES}

BEERS, R. F. \& SIZER, I. W. (1952). A spectrophotometric method for measuring the breakdown of hydrogen peroxide by catalase. Journal of Biological Chemistry 159, 133-140.

Blake, M. S., Johnston, K. H., Russell-Jones, G. J. \& GotTsChliCh, E. C. (1984). A rapid, sensitive method for detection of alkaline phosphataseconjugated anti-antibody on Western blots. Analytical Biochemistry 136, 157-179.

de Boer, E., Plat, H., Tromp, M. G. M., Wever, R., Franssen, M. C. R., van der Plas, H. C., MeiJer, E. M. \& SCHOEMAKeR, H. E. (1987). Vanadium containing bromoperoxidase: an example of an oxidoreductase with high operation stability in aqueous and organic media. Biotechnology and Bioengineering 30, 607-610.

Claiborne, A. \& Fridovich, I. (1979). Purification of the $o$-dianisidine peroxidase from Escherichia coli B. Journal of Biological Chemistry 254, 4245-4252.

Clarke, J. T. (1964). Simplified disc (polyacrylamide gel) electrophoresis. Annals of the New York Academy of Sciences 121, 428-436.

Doull, J., Ahmed, Z., Stuttard, C. \& Vining, L. C. (1985). Isolation and characterization of Streptomyces venezuelae mutants blocked in chloramphenicol biosynthesis. Journal of General Microbiology 131, 97-104.

GlenN, J. K. \& Gold, M. (1985). Purification and characterization of an extracellular $\mathrm{Mn}$ (II)-dependent peroxidase from the lignin-degrading basidiomycete, Phanerochaete chrysosporium. Archives of Biochemistry and Biophysics 242, 329-341.

GrIFFIN, B. W. \& ASHLEY, P. L. (1984). Evidence for a radical mechanism of halogenation of monochlorodimedone catalyzed by chloroperoxidase. Archives of Biochemistry and Biophysics 233, 188-196.

Hewson, W. D. \& HAGER, L. P. (1980). Bromoperoxidases and halogenated lipids in marine algae. Journal of Phycology 16, 340-345.

LAEMMLI, U. K. (1970). Cleavage of structural proteins during the assembly of the head of bacteriophage T4. Nature, London 227, 680-685.

LiU, T.-N., M'Timkulu, T., Geigert, J., Wolf, B., Neidleman, S. L., Silva, D. \& Hunter-Cevera, J. C. (1987). Isolation and characterization of a novel nonheme chloroperoxidase. Biochemical and Biophysical Research Communications 142, 329-333.

LOO, T. L., Burger, J. W. \& Adamson, R. H. (1964). Bromination of phthalein dyes by the uterus of the dogfish, Squalus acanthias. Proceedings of the Society of Experimental Biology and Medicine 114, 60-63.

MAURER, H. R. (1968). Disk-Elektrophorese: Theorie und Praxis der diskontinuierlichen Polyacrylamidgelelektrophorese. Berlin: Walter de Gruyter.

MORRIS, D. R. \& HAGER, L. P. (1966). Chloroper- oxidase. I. Isolation and properties of the crystalline glycoprotein. Journal of Biological Chemistry 241, 1763-1768.

NADLER, V., Goldberg, I. \& Hochman, A. (1986). Comparative study of bacterial catalases. Biochimica et biophysica acta 882, 234-241.

Neidleman, S. L. \& Geigert, J. (1986). Biohalogenation: Principles, Roles and Basic Applications. Chichester: Ellis Horwood/John Wiley.

OUCHTERLONY, Ö. (1949). Antigen-antibody reactions in gels. Acta Pathologica et Microbiologica Scandinavica 26, 507-515.

vaN PÉE, K.-H. \& Lingens, F. (1985). Purification and molecular and catalytic properties of bromoperoxidase from Streptomyces phaeochromogenes. Journal of General Microbiology 131, 1911-1916.

van Pée, K.-H., Sury, G. \& Lingens, F. (1987). Purification and properties of a nonheme bromoperoxidase from Streptomyces aureofaciens. Biological Chemistry Hoppe-Seyler 368, 1225-1232.

Schoendaum, G. R. \& Chance, B. (1976). In The Enzymes, 2nd edn, pp. 363-408. Edited by E. D. Boyer. New York, San Francisco \& London: Academic Press.

Shannon, L. M., Kay, E. \& Lew, Y. (1966). Peroxidase isoenzymes from horseradish roots. Journal of Biological Chemistry 241, 2166-2172.

SiChaK, S. P. \& Dounce, A. L. (1986). Analysis of the peroxidatic mode of action of catalase. Archives of Biochemistry and Biophysics 249, 286-295.

Simonsen, J. N., Paramasigmani, K., Vining, L. C., McInNes, A. G., Walter, J. A. \& Wright, J. L. C. (1978). Biosynthesis of chloramphenicol. Studies on the origin of the dichloroacetyl moiety. Canadian Journal of Microbiology 24, 136-142.

Spielman, H., ERickson, R. P. \& Epstein, C. J. (1974). The production of antibodies against mammalian LDH-1. Analytical Biochemistry 59, 462-467.

Vining, L. C. \& Westlake, D. W. S. (1984). Chloramphenicol: properties, biosynthesis and fermentation. In Biotechnology of Industrial Antibiotics, pp. 387-41 1. Edited by E. J. Vandamme. New York: Marcel Dekker.

Wiesner, W., VAN PÉE, K.-H. \& Lingens, F. (1985). Purification and properties of bromoperoxidase from Pseudomonas pyrrocinia. Biological Chemistry Hoppe-Seyler 366, 1085-1091.

Wiesner, W., van PéE, K.-H. \& Lingens, F. (1986). Detection of a new chloroperoxidase in Pseudomonas pyrrocinia. FEBS Letters 209, 321-324.

WIesner, W., van Pée, K.-H. \& Lingens, F. (1988). Purification and characterization of a novel bacterial non-heme chloroperoxidase from Pseudomonas pyrrocinia. Journal of Biological Chemistry 263, 13725-13732. 